\title{
Prevalence of Listeria species including L. monocytogenes from apparently healthy animals at Baroda Zoo, Gujarat State, India
}

\author{
Mahendra Mohan Yadav ${ }^{1}$, Ashish Roy ${ }^{2}$, Bharat Bhanderi ${ }^{3}$ \& R.G. Jani ${ }^{4}$ \\ ${ }^{1}$ Assistant Professor, Mahatma Phule Krishi Vidyapeeth, Rahuri, Maharashtra 413722, India \\ 2. Professor, ${ }^{3}$ M.V.Sc Scholar, Department of Veterinary Microbiology, ${ }^{4}$ Professor, Department of Veterinary Medicine, \\ College of Veterinary Science \& Animal Husbandry, Anand, Gujarat 388001, India \\ Email: ${ }^{1}$ drmahendrayadav@rediffmail.com (corresponding author), ${ }^{2}$ aroyvet@yahoo.co.in, ${ }^{3}$ bbbhanderi@yahoo.co.in, ${ }^{4}$ rgjani@aau.in
}

Date of publication (online): 26 July 2011 Date of publication (print): 26 July 2011 ISSN 0974-7907 (online) | 0974-7893 (print)

Editor: Ulrike Streicher

\section{Manuscript details:}

Ms \# 02094

Received 06 November 2008

Final received 25 May 2011

Finally accepted 01 June 2011

Citation: Yadav, M.M., A. Roy, B. Bhanderi \& R.G. Jani (2011). Prevalence of Listeria species including $L$. monocytogenes from apparently healthy animals at Baroda Zoo, Gujarat State, India. Journal of Threatened Taxa 3(7): 19291935.

Copyright: () Mahendra Mohan Yadav, Ashish Roy, Bharat Bhanderi \& R.G. Jani 2011 Creative Commons Attribution 3.0 Unported License. JoTT allows unrestricted use of this article in any medium for non-profit purposes, reproduction and distribution by providing adequate credit to the authors and the source of publication.

For Author Details and Author Contribution see end of this article

Acknowledgements: We thank Dean/Principal, College of Veterinary Science and Animal Husbandry, Anand for providing necessary facilities to carry out the research work. We also thank Dr. C.G. Joshi, Professor, Animal Biotechnology Laboratory, College of Veterinary Science and Animal Husbandry, Anand for technical assistance in molecular work.
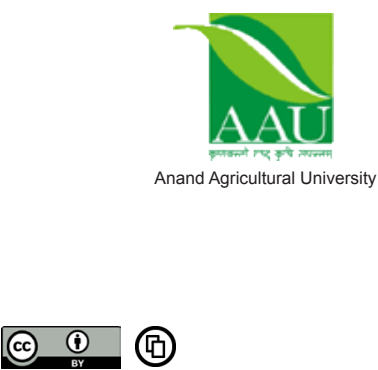

OPEN ACCESS | FREE DOWNLOAD

\begin{abstract}
Listeriosis is a infectious bacterial disease of domestic and wild animals and humans. A total of 56 faecal samples were collected from mammals and birds at Baroda Zoo, Vadodara, Gujarat State, India. Confirmation of the isolates was based on biochemical tests followed by phenotypic characterization by hemolysis on sheep blood agar, Christie Atkins Munch-Petersen (CAMP) test, phosphatidylinositol-specific phospholipase C (PI-PLC) assay and phosphatidylcholine-specific phospholipase C (PC-PLC) assay. The isolates were subjected to genotypic characterization with the help of polymerase chain reaction (PCR) assay for five virulence-associated genes, plcA, prfA, hlyA, actA and iap. Listeria monocytogenes isolates were further subjected to multiplex-PCR based serotyping. From 56 samples three $(5.36 \%)$ were found positive for Listeria spp. of which one $(1.79 \%)$ was identified as $L$. monocytogenes and two $(3.57 \%)$ were identified as $L$. innocua. The isolate of $L$. monocytogenes was hemolytic, CAMP positive, PI-PLC positive, hlyA, pclA and prfA positive by PCR and turned out to be PC-PLC positive and was serotyped as $4 \mathrm{~b}$.
\end{abstract}

Keywords: CAMP, Listeria monocytogenes, PCR, serotyping, serovar, zoo animals.

\section{INTRODUCTION}

Listeriosis is an important bacterial disease of animals and a zoonosis with a broad distribution; Listeria monocytogenes is the major pathogen causing listeriosis and is of significant economic and health concern as it causes disease in a wide variety of animals including sheep, goats, cattle, buffaloes, dogs, horses, chickens, rabbits and also human beings (Katiyar 1960).

Information on the serovar allows discrimination between isolates belonging to an outbreak and those that are not part of the outbreak. All major outbreaks of listeriosis are caused by serovar $4 \mathrm{~b}$, which is primarily responsible for ruminant listeriosis (Rocourt \& Seeliger 1985; Radostits et al. 1994). This strain is infrequent in foods compared to $1 / 2$ a strains (Buchrieser et al. 1993; Farber \& Peterkin 1991). The procedure adopted to investigate outbreaks relies on serovar characterization for isolated strains.

Although 13 serovars are described for L. monocytogenes, at least $95 \%$ of the strains isolated from foods and patients belong to the serovars 1/2a, 1/2b and 4b (Seeliger \& Hohne 1979; Tappero et al. 1995; Graves et al. 1999).

In Gujarat State, India, there has been no report of Listeria sp. from wild animals; although L. monocytogenes has been isolated from wild animals in Nagpur City in the neighbouring Maharasthra by Kalorey et 
al. (2006). It is very important for public health to understand the prevalence of Listeria in wild animals, since wild animals whether captive or free-ranging may act as a reservoir for the disease. The purpose of this study was to determine the prevalence of Listeria sp. in apparently healthy zoo animals and to characterize the isolates phenotypically and genotypically.

\section{MATERIALS AND METHODS}

Bacteria: Strains of L. monocytogenes 4b (MTCC 1143), Staphylococcus aureus (MTCC 1144), Rhodococcus equi (MTCC 1135), Escherichia coli (MTCC 443) were obtained from the Microbial Type Culture Collection and Gene Bank, Institute of Microbial Technology, Chandigarh, India. Different strains of Staphylococcus aureus (ATCC 25923), Streptococcus agalactiae (NCIM 2401), Bacillus spp. (ATCC 6638) and Pseudomonas aeruginosa (ATCC 27853) were obtained from the Department of Veterinary Microbiology, College of Veterinary Science \& Animal Husbandry, Anand, India.

Samples: A total of 56 faecal samples were collected from mammals (9) and birds (47) of Baroda Zoo. The animals screened were Sambar (2), Chital (3), Black Buck (3) Nilgai (1) and that of birds were Love birds (5), Cockatoo (5), Rosella (2), Macaw (3), Dove (10), Emu (5), Conur (4), Koel (2), Cockatiel (5), Lori (6).

Isolation of Listeria: Isolation of listeriae from the faecal samples of the animals followed the method of the US Department of Agriculture (USDA) described by McClain \& Lee (1998) with some modifications.

Samples were enriched by two-step enrichment in University of Vermont (UVM) medium -I and II. Each of the faecal swabs was aseptically transferred into 10ml UVM-I. In UVM-I medium the samples were incubated at $30^{\circ} \mathrm{C}$ for $24 \mathrm{hr}$. Then the samples were incubated in the UVM -II medium at $30^{\circ} \mathrm{C}$ for up to seven days. After $24 \mathrm{hr}, 48 \mathrm{hr}$ and seven days of incubation samples were simultaneously streaked onto Dominguez-Rodriguez isolation agar (DRIA), PALCAM agar, and Oxford agar.

Confirmation of the isolates: Morphologically typical colonies were verified by Gram's staining, catalase reaction, tumbling motility at $20-25{ }^{\circ} \mathrm{C}$, Methyl Red-Voges Proskauer (MR-VP) reactions, nitrate reduction and fermentation of sugars (rhamnose, xylose, mannitol and $\alpha$-methylD - mannopyranoside).

\section{Phenotypic characterization}

Haemolysis on sheep blood agar (SBA): All the Listeria isolates were tested for the type ( $\alpha$ or $\beta$ ) and the degree (narrow or wider) of hemolysis on SBA. The isolates were streaked onto 7\% SBA plates and incubated at $37^{\circ} \mathrm{C}$ in a humidified chamber for $24 \mathrm{hr}$. After that they were examined for haemolytic zones around the colonies. Interpretation of the haemolytic reaction was based on the formation of a typical wide and clear zone of haemolysis ( $\beta$-haemolysis) representing $L$. ivanovii and formation of a narrow zone of haemolysis ( $\alpha$-haemolysis) representing $L$. monocytogenes or L. seeligeri.

Christie, Atkins, Munch-Petersen (CAMP) test: The standard strains of Staphylococcus aureus and Rhodococcus equi were grown overnight on SBA plates at $37^{\circ} \mathrm{C}$ in a humidified chamber. The colonies were then also streaked onto freshly prepared $7 \%$ SBA plates in a manner that the streaks were wide apart and parallel to each other. In between the parallel streaks of $S$. aureus and $R$. equi the Listeria isolates were streaked at $90^{\circ}$ angles and $3 \mathrm{~mm}$ apart before incubating them at $37^{\circ} \mathrm{C}$ for $24 \mathrm{hr}$. In case of a CAMP positive reaction the synergistic effect of the haemolysins would lead to a wider zone of complete haemolysis between a Listeria strain and the $S$. aureus or $R$. equi strain. The Listeria isolates with CAMP-positivity against $S$. aureus were characterized as L. monocytogenes and those with CAMP positivity against $R$. equi were characterized as L. ivanovii .

Phosphatidylinositol-specific phospholipase C (PI-PLC) assay: All the phenotypically characterized Listeria isolates were assayed for PI-PLC activity following the method of Leclercq (2004) with certain modifications. Listeria isolates were incubated overnight on $7 \%$ SBA plates at $37^{\circ} \mathrm{C}$ in a humidified chamber. All L. monocytogenes isolates were streaked on L. mono differential agar (Hi Media Ltd, Mumbai, India) in order to assess PI-PLC activity. The inoculated plates were incubated at $37^{\circ} \mathrm{C}$ in a humidified chamber for $24 \mathrm{hr}$. Light blue colonies showing formation of a halo around the inoculation site were considered positive.

Phosphatidylcholine-specific phospholipase C (PC-PLC) Assay: an egg-yolk opacity test was 
Table 1. Details of primers for amplification of virulence marker associated genes of L. monocytogenes

\begin{tabular}{|c|c|c|c|c|}
\hline Target gene & \multicolumn{2}{|c|}{ Primer Sequence } & $\begin{array}{l}\text { Product } \\
\text { size (bp) }\end{array}$ & Reference \\
\hline \multirow{2}{*}{ plc A } & Forward & 5'- CTG CTT GAG CGT TCA TGT CTC ATC CCC C - 3' & \multirow{2}{*}{1484} & \multirow{2}{*}{ Notermans et al. 1991a } \\
\hline & Reverse & 5'- CAT GGG TTT CAC TCT CCT TCT AC - 3' & & \\
\hline \multirow{2}{*}{ prfA } & Forward & 5'- CTG TTG GAG CTC TTC TTG GTG AAG CAA TCG - 3' & \multirow{2}{*}{1060} & \multirow{2}{*}{ Notermans et al. 1991a } \\
\hline & Reverse & 5'- AGC AAC CTC GGT ACC ATA TAC TAA CTC - 3' & & \\
\hline \multirow{2}{*}{ hly A } & Forward & 5'- GCA GTT GCA AGC GCT TGG AGT GAA - 3' & \multirow{2}{*}{456} & \multirow{2}{*}{ Paziak-Domanska et al. 1999} \\
\hline & Reverse & 5'- GCA ACG TAT CCT CCA GAG TGA TCG - 3' & & \\
\hline \multirow{2}{*}{ iap A } & Forward & 5'- ACA AGC TGC ACC TGT TGC AG - 3' & \multirow{2}{*}{131} & \multirow{2}{*}{ Furrer et al. 1991} \\
\hline & Reverse & 5'- TGA CAG CGT GTG TAG TAG CA -3' & & \\
\hline \multirow{2}{*}{$\operatorname{act} \mathrm{A}$} & Forward & 5'- CGC CGC GGAAAT TAAAAAAAG A - 3' & \multirow{2}{*}{839} & \multirow{2}{*}{ Suarez et al.2001 } \\
\hline & Reverse & 5'- ACG AAG GAA CCG GGC TGC TAG - 3' & & \\
\hline \multirow{2}{*}{ prs } & Forward & 5'- GCT GAA GAG ATT GCG AAA GAA G-3' & \multirow{2}{*}{370} & \multirow{2}{*}{ Doumith et al. 2004} \\
\hline & Reverse & 5'- CAAAGAAAC CTT GGA TTT GCG G -3' & & \\
\hline
\end{tabular}

conducted to examine the PC-PLC activity of the isolates. Tryptic soy agar (Hi Media Ltd. Mumbai, India) plates were prepared with $2.5 \%$ egg-yolk emulsion (Hi Media Ltd. Mumbai, India) and 2.5 $\% \mathrm{NaCl}$ and a $\mathrm{pH}$ of $6.5-7$. Listeria isolates were streaked onto the agar surfaces and incubated at $37^{\circ} \mathrm{C}$ for 36-72 hr. Formation of opaque zones surrounding the colonies was considered positive (Coffey et al. 1996).

\section{Genotypic Characterization}

Polymerase chain reaction (PCR) based detection of virulence-associated genes: The standard strain of L. monocytogenes (MTCC 1143) was incubated overnight in brain heart infusion at $37^{\circ} \mathrm{C}$. About $0.5 \mathrm{ml}$ of the culture was then centrifuged in a microcentrifuge (Sigma, USA) at $6000 \times \mathrm{g}$ for 10 min. The recovered pellet was resuspended in $100 \mu \mathrm{l}$ of sterilized DNAse and RNAse-free milliQ water (Millipore, USA), heated in a boiling water bath for $10 \mathrm{~min}$ and then shock chilled in crushed ice. The obtained lysate $(5 \mu \mathrm{l})$ was used as a DNA template in PCR reaction mixture. For the amplification of the virulence associated genes of L. monocytogenes, hemolysin gene (hlyA), regulatory gene (prfA), Phosphatidylinositol phospholipase $\mathrm{C}$ gene (plcA), Actin gene (actA) and p60 gene (iap), primers synthesized by Sigma Aldrich, USA were used. Details about primers and PCR product sizes are shown in Table 1. PCR conditions followed methods described by multiple authors (Furrer et al. 1991; Notermans et al. 1991a; Paziak-Domanska et al. 1999; Suarez \& Vazquez-Boland 2001) with some modifications. Conditions affecting the sensitivity and specificity of the reaction were optimized. Such conditions are for example the concentrations of $\mathrm{MgCl}_{2}$, primers and Taq DNA polymerase, the annealing temperatures $\left(50-60^{\circ} \mathrm{C}\right)$ and the number of cycles for amplification of the target gene.

Based on optimization trials, the standard PCR protocol for a $50 \mu$ reaction mixture included $5.0 \mu \mathrm{l}$ of $10 \times \mathrm{PCR}$ buffer $(100 \mathrm{~mm}$ Tris- $\mathrm{HCl}$ buffer with $\mathrm{pH} 8.3$ containing $500 \mathrm{mM} \mathrm{KCl}, 15 \mathrm{mM} \mathrm{MgCl}_{2}$ and $0.01 \%$ gelatin), $1 \mu \mathrm{l}$ of $10 \mathrm{mM}$ dNTP mix (a final concentration of $0.2 \mathrm{mM}$; Sigma, USA), $4 \mu 1$ of $25 \mathrm{mM}$ $\mathrm{MgCl}_{2}$ (a final concentration of $2 \mathrm{mM}$ ) and $10 \mu \mathrm{M}$ of a primer set containing forward and reverse primers at a concentration of $0.1 \mu \mathrm{M}$ of each primer, $1 \mathrm{U}$ of Taq DNA polymerase (Sigma, USA), $5 \mu 1$ of cell lysate and sterilized milliQ water to make up the reaction volume.

The $0.2 \mathrm{ml} \mathrm{PCR}$ tube containing the reaction mixture was tapped thoroughly with a finger and then flash spun in a micro centrifuge. The DNA amplification was performed in a Master Cycler Gradient Thermocycler with a preheated lid (Eppendorf, Hamburg, Germany). The cycling conditions for PCR included an initial denaturation at $95^{\circ} \mathrm{C}$ for two minutes followed by 35 cycles each of $15 \mathrm{~s}$ denaturation at $95^{\circ} \mathrm{C}, 30 \mathrm{~s}$ annealing at $60^{\circ} \mathrm{C}$ and $90 \mathrm{~s}$ extension at $72^{\circ} \mathrm{C}$, followed by a final extension of $10 \mathrm{~min}$ at $72^{\circ} \mathrm{C}$ and kept at $4^{\circ} \mathrm{C}$. All the five sets of primers for virulence-associated genes 
Table 2. Details of primers for amplification of target genes of Listeria monocytogenes employed in serotyping PCR

\begin{tabular}{|c|c|c|c|c|c|}
\hline $\begin{array}{l}\text { Gene } \\
\text { target }\end{array}$ & \multicolumn{2}{|c|}{$\begin{array}{l}\text { Primer } \\
\text { Sequence }\end{array}$} & $\begin{array}{l}\text { Product } \\
\text { Size (bp) }\end{array}$ & $\begin{array}{l}\text { Serovar } \\
\text { specificity }\end{array}$ & $\begin{array}{l}\text { Protein encoded by the } \\
\text { target gene }\end{array}$ \\
\hline \multirow{2}{*}{ Imo0737 } & $\mathrm{F}$ & 5'- AGG GCT TCAAGG ACT TAC CC- 3' & \multirow{2}{*}{691} & \multirow{2}{*}{$1 / 2 a$} & \multirow{2}{*}{ Unknown, no similarity } \\
\hline & $\mathrm{R}$ & 5'- ACG ATT TCT GCT TGC CAT TC - 3' & & & \\
\hline \multirow{2}{*}{ ORF2819 } & $\mathrm{F}$ & 5'- AGC AAA ATG CCA AAA CTC GT - 3' & \multirow{2}{*}{471} & \multirow{2}{*}{$1 / 2 b$ and $4 b$} & \multirow{2}{*}{$\begin{array}{l}\text { Putative transcriptional } \\
\text { regulator }\end{array}$} \\
\hline & $\mathrm{R}$ & 5'- CAT CAC TAAAGC CTC CCA TTG - 3' & & & \\
\hline \multirow{2}{*}{ ORF2110 } & $\mathrm{F}$ & 5'- AGT GGA CAA TTG ATT GGT GAA - 3' & \multirow{4}{*}{597} & \multirow{2}{*}{$4 b$} & \multirow{2}{*}{ Putative secreted protein } \\
\hline & $\mathrm{R}$ & 5'- CAT CCA TCC CTT ACT TTG GAC- 3' & & & \\
\hline \multirow{2}{*}{ prs } & $\mathrm{F}$ & 5'- GCT GAA GAG ATT GCG AAA GAA G- 3' & & \multirow{2}{*}{ All Listeria species } & \multirow{2}{*}{$\begin{array}{l}\text { Putative phosphoribosyl } \\
\text { pyrophosphate synthetase }\end{array}$} \\
\hline & $\mathrm{R}$ & 5'- CAAAGA AAC CTT GGA TTT GCG G -3' & & & \\
\hline
\end{tabular}

were amplified under similar PCR conditions and amplification cycles. The resulting PCR products were analyzed by agarose gel electrophoresis $(1.5 \%$; low melting temperature agarose L), stained with ethidium bromide $(0.5 \mu \mathrm{g} / \mathrm{ml})$ and visualized by a UV transilluminator (UVP Gel Seq Software, England).

Multiplex PCR based serotype detection of Listeria monocytogenes isolates: The multiplex PCR assay was standardized for the detection of serovars $1 / 2 \mathrm{a}, 1 / 2 \mathrm{~b}$ and $4 \mathrm{~b}$ of $L$. monocytogenes following the methodology described by Doumith et al. (2004). The primers for detection of $L$. monocytogenes 0737 gene (lmo0737), transcriptional regulator gene (ORF2819), secreted protein gene (ORF2110) and phosphoribosyl pyrophosphate synthetase gene (prs) of L. monocytogenes used in this study were synthesized from Sigma Aldrich. Details of the primer sequences are shown in Table 2.

The PCR was set for $50 \mu 1$ reaction volume. For the detection of L. monocytogenes serotypes concentrations of molecular biologicals, annealing temperature and number of cycles for amplification of the target genes were varied until optimal conditions were determined. The optimal reaction mixture for PCR contained 5.0 $\mu 1$ of $10 x$ PCR buffer (), $1.5 \mu 1 \mathrm{dNTP}$ mix, $4 \mu 1$ of $25 \mathrm{mM} \mathrm{MgCl}_{2}$ and $100 \mu \mathrm{M}$ of forward and reverse primers for each serovar $1 / 2 \mathrm{a}, 1 / 2 \mathrm{~b}$ and $4 \mathrm{~b}$ (final concentration $0.1 \mu \mathrm{M}$ each) and $10 \mu \mathrm{M}$ of forward and reverse primers for each Listeria spp. (final concentration $0.1 \mu \mathrm{M}$ each), 2 units of Taq DNA Polymerase, $5 \mu 1$ of cell lysate and sterilized milliQ water to make up the reaction volume.

The $0.2 \mathrm{ml}$ PCR tube containing the reaction mixture was flash spun in a micro centrifuge. The reaction was performed in a Px2 Thermal cycler with a pre-heated lid (Thermo electronic corporation, USA). The cycling conditions included an initial denaturation for five minutes at $94^{\circ} \mathrm{C}$ followed by 35 cycles of denaturation for 30 seconds at $94^{\circ} \mathrm{C}, 75$ seconds of annealing at $54^{\circ} \mathrm{C}$ and 75 seconds of extension at $72^{\circ} \mathrm{C}$. It was followed by 10 minutes of extension at $72^{\circ} \mathrm{C}$ and was finally held for 30 minutes at $4^{\circ} \mathrm{C}$. After the reaction, PCR products were kept at $-20^{\circ} \mathrm{C}$ until further analysis by agarose gel electrophoresis.

\section{RESULTS}

Isolation of Listeria monocytogenes: From 56 samples, $3(5.36 \%)$ were found positive for Listeria spp., of which $1(1.79 \%)$ was identified as $L$. monocytogenes and $2(3.57 \%)$ as L. innocua.

Phenotypic characters: One of the Listeria isolates was CAMP positive and showed the characteristic enhancement of haemolytic zone with $S$. aureus. Two of the isolates did not show enhancement of the hemolytic zone either with $S$. aureus or R. equi. The CAMP positive isolate was also found to be positive for PI-PLC and PC-PLC assay and was confirmed to be L. monocytogenes.

Genotypic characters: The standardized PCR allowed amplification of virulence associated genes of L. monocytogenes plcA, prfA, actA, hlyA and iap to their respective base pairs, $1484 \mathrm{bp}, 1060 \mathrm{bp}, 839 \mathrm{bp}$, $456 \mathrm{bp}$ and $131 \mathrm{bp}$, and allowed visualization of each virulence associated gene, each gene represented by a single band in the corresponding region of the DNA ladder. The primers used in the PCR were specific to the target genes and all the five genes were detected in standard strains of L. monocytogenes, whereas none 
of the genes was detected in the cultures of the other bacterial species cultures (Staphylococcus aureus, Rhodococcus equi, Escherichia coli, Streptococcus agalactiae, Bacillus spp. and Pseudomonas. aeruginosa).

All three Listeria isolates were subjected to standardized PCR for detection of five virulenceassociated genes. Only one isolate, which has been confirmed as L. monocytogenes, showed amplification for four of the virulence-associated genes (hlyA, plcA, prfA and actA), the fifth gene (iap) was not detected. The isolates confirmed as L. innocua failed to amplify any of the five virulence-associated genes.

The multiplex PCR was standardized for detection of three major serotypes of $L$. monocytogenes $1 / 2 \mathrm{a}$, $1 / 2 \mathrm{~b}$ and $4 \mathrm{~b}$ by targeting various genes like Imo0737, ORF2819, ORF2110 and prs which were coding unknown protein, putative transcriptional regulator, putative secreted protein and putative phosphoribosyl pyrophosphate. The isolate showed amplification of three molecular size bands 471 bp, $597 \mathrm{bp}$ and $370 \mathrm{bp}$ corresponding to the genes, ORF2819, ORF2110 and prs, respectively.

All the isolates biochemically identified as Listeria, including the two isolates identified as L. inocua, amplified $370 \mathrm{bp}$ product corresponding to gene prs. This was used as an internal amplification control.

The single $L$. monocytogenes isolate was serotyped as $4 \mathrm{~b}$ by multiplex PCR assay.

\section{DISCUSSION}

Prevalence of Listeria spp. and $L$. monocytogenes from zoo animals: In a zoo setting infectious diseases are the main cause for animal losses as well as a concern for public health. Infectious diseases are caused by bacteria, fungi, parasites, or viruses. Control of such infections is difficult because of the design and purpose of the zoo itself. In a modern zoo we strive to show the animal under natural conditions and it is impossible to provide pathogen free soil, water or air.

However, infectious diseases can be minimized with appropriate recognition of the problem and training of personnel to limit the spread of infectious organisms.

In the present study $5.36 \%$ of the animals checked were found positive for Listeria spp, of which $1.79 \%$ was L. monocytogenes and $3.57 \%$ were L. innocua. This is a fairly low infection rate compared to the results of Arumugaswamy \& Gibson (1999), who reported 18.6\% of the animals excreting $L$. monocytogenes in Taronga Zoological Garden, New South Wales, Australia, and Bauwens et al. (2003), who reported 7.5\% of all wild animals in zoos were carrying pathogenic Listeria. Faeces of healthy animals have often been reported to contain L. monocytogenes (Skovgaard \& Morgen, 1988). In India, Kalorey et al. (2006) isolated L. monocytogenes from eight $(16.0 \%)$ of 50 faecal samples of healthy captive wild animals.

The presence of Listeria sp. including $L$. monocytogenes without clinical signs in zoo animals may reflect that these animals were in the incubation period of a disease or they are not susceptible to the organism. Listeria sp. are ubiquitous in nature and are commonly found in the intestines of animals and humans without necessarily causing disease.

In a zoo setting, the keeping of many species of animals in a restricted area could lead to an increased number of clinically healthy carriers posing an infection risk to susceptible animals, personnel and visitors.

In domestic cattle the reported rate of Listeria spp. identified in the faeces was in the range of 3.1-45.8 $\%$ (Gronstel 1979; Loken et al. 1982). In comparison to farm animals the prevalence of Listeria sp. and $L$. monocytogenes in zoo animals found in our study is very low. This might be a result of individual care, isolation and better hygienic measures.

For domestic cattle the usual route of infection is via contaminated food. However, silage was not fed to the herbivores at the zoo. All Listeria in our study were found in samples from carnivores and here the raw meat products fed to the animals may be the source of infection.

The rate of isolation of Listeria sp., $L$. monocytogenes and L. innocua in the present study, was very low; this was probably due to several factors that were compounded by an already low incidence of the organism. One of the major factors was the extremely high microbial load of feces. Our findings thus were consistent with that of Siragusa et al. (1993) who reported that $L$. innocua was the most frequent species of Listeria isolated from cattle.

The PCR assay in for detection of virulence associated genes, the iap gene from the $L$. 
monocytogenes isolate was not amplified whereas the other four virulence-associated genes showed specific amplification. The iap gene might be absent or there is mutation in primer binding region. However, this did not reflect in any of the biochemical or phenotypical reactions of the isolate. Nishibori et al. (1995) has shown that the PCR detection of only one virulence associated gene is not always sufficient to identify L. monocytogenes. We have shown that at least one of the virulence associated genes can miss without an alteration of the isolate. The minimal number of virulence associated genes, which allow for exact identification of L. monocytogenes, must therefore still be determined. Geographic differences in the global distribution of serotypes apparently exist, but our data is not sufficient to allow for major conclusions. Serotype $4 b$ however, the serotype identified in our study, has been found to be the serotype predominantly responsible for the animal listeriosis and Listeria associated foodborne outbreaks. So this result is of critical importance for the further epidemiological investigations.

In conclusion, it is clear that wild animals can act as reservoirs or carriers of L. monocytogenes. Listeria species were detected in wild animals that moved broadly and that had homeranges overlapping with areas inhabited by humans.

For public health, it is important to clarify the epidemiological relationship between $L$. monocytogenes in wild animals and L. monocytogenes in human cases of listeriosis and food contamination. In a zoo setting, infection risks need to be considered not only among the various zoo animal populations, but also with regard to human contacts.

\section{REFERENCES}

Arumugaswamy, R. \& L.F. Gibson (1999). Listeriosis in zoo animals and rivers. Australian Veterinary Journal 77: 819-820.

Bauwens, L., F. Vercammmen \& A. Hertsens (2003). Detection of pathogenic Listeria spp. in zoo animal faeces: use of chromogenic separation and a chromogenic isolation medium. Veterinary Microbiology 91: 115-123.

Buchrieser, C., R. Brosch, B. Catimel \& J. Rocourt (1993). Pulsed-field gel electrophoresis applied for comparing Listeria monocytogenes strains involved in outbreaks. Canadian Journal of Microbiology 39: 395-401.

Coffey, A., F.M. Rombouts \& T. Abee (1996). Influence of environmental parameters on phosphatidylcholine phospholipase $\mathrm{C}$ production in Listeria monocytogenes: a convenient method to differentiate L. monocytogenes from other Listeria species. Applied and Environmental Microbiology 62: 1252-1256.

Doumith, M., C. Buchrieser, P. Glaser, C. Jacquet \& P. Martin (2004). Differentiation of the major Listeria monocytogenes Serovars by Multiplex PCR. Journal of Clinical Microbiology 42: 3819-3822.

Farber, J.M. \& P.I. Peterkin (1991). Listeria monocytogenes, a food-borne pathogen. Microbiological Reviews 55: 476511.

Furrer, B., U. Candrian, C. Hoefelein \& J. Luethy (1991). Detection and identification of Listeria monocytogenes in cooked sausage products and in milk by in-vitro amplification of haemolysin gene fragments. Journal of Applied Bacteriology 70: 372-379.

Graves, L.M., B. Swaminathan \& S.B. Hunter (1999). Subtyping Listeria monocytogenes, pp. 251-297. In: Ryser, E.T. \& E.H. Marth (ed.). Listeria, Listeriosis and Food Safety. Marcel Dekker Inc., New York, N.Y.

Gronstel, H. (1979). Listeriosis in sheep: Listeria monocytogenes excretion and immunological state in sheep in flock with clinical listeriosis. Acta Veterinaria Scandinavica 20 : 417-428.

Kalorey, D.R., N.V. Kurkure, S.R. Warke, D.B. Rawool, S.V.S. Malik \& S.B. Barbuddhe (2006). Isolation of pathogenic Listeria monocytogenes in faeces of wild animals in captivity. Comparative Immunology, Microbiology \& Infectious Diseases 29: 295-300.

Katiyar, R.D. (1960). Listeriosis amongst sheep and goats in Utter Pradesh. Indian Veterinary Journal 37: 620-623.

Leclercq, A. (2004). A typical colonial morphology and low recoveries of Listeria monocytogenes strains on Oxford, PALCAM, Rapid'L.mono and ALOA solid media. Journal of Microbiological Methods 57: 251-258.

Loken, T., E. Aspoy \& H. Gronstol (1982). Listeria monocytogenes excretion and humoral immunity in goats in a healthy herd. Acta Veterinaria Scandinavica 23: 392 399.

McClain, D., \& W.H. Lee (1988). Devepolment of USDAFSIS method for isolation of Listeria monocytogenes from raw meat and poultry. Journal of the Association of Official Analytical Chemists 71: 660-663.

Notermans, S. H. W., J. Dufrenne, M. Leimeister-Wachter, E. Domann, \& T. Chakraborty (1991). Phosphatidylinositolspecific phospholipase $\mathrm{C}$ activity as a marker to distinguish between pathogenic and non-pathogenic Listeria species. Applied and Environmental Microbiology 57: 2666-2670.

Paziak-Domanska, B., E. Bogulawska, M. WiekowskaSzakiel, R. Kotlowski, B. Rozalska, M. Chmiela, J. Kur, W. Dabrowski \& W. Rudnicka (1999). Evaluation of the API test, phosphatidylinositol-specific phospholipase $\mathrm{C}$ activity and PCR method in identification of Listeria monocytogenes in meat foods. Federation of European Microbiological Society Microbiology Letters 171: 209- 
214.

Radostits O.M., D.C. Blood \& C.C. Gay (1994). Disease caused by Listeria spp. pp. 660-666. In: Veterinary Medicine. $8^{\text {th }}$ Edition. ELB509 Bailliere Tindall, London.

Rocourt, J. \& H.P.R. Seeliger (1985). Distribution des especesdu genre Listeria. Zentralblatt Fur Bakteriologie Mikrobiologie Und Hygiene 259: 317-330.

Seeliger, H.P.R. \& K. Hohne (1979). Serotyping of Listeria monocytogenes and related species. Methods in Microbiology 13: 31-49.

Skovgaard, N. \& C.A. Morgen (1988). Detection of Listeria spp. In faeces from animals, in feeds and in raw foods of animal origin. International Journal of Food Micobiology 6: 229-242.

Siragusa, G.R., J.S. Dickson \& E.K. Daniels (1993). Isolation of Listeria spp. from feces of feedlot Catte. Journal of Food Protection 56: 102-105.

Suarez, M. \& J.A. Vazquez-Boland (2001). The bacterial actin nucleter protein ActA is involved in epithelial cell invasion by Listeria monocytogenes. PUBMED [Accession No. AF103807].

Tappero, J.W., A. Schuchat, K.A. Deaver, L. Mascola \& J.D. Wenger (1995). Reduction in the incidence of human listeriosis in the United States. Effectiveness of prevention efforts? Journal of the American Medical Association 273: 11181122 .
Author Details: Mahendra Mohan Yadav is currently working as a Assistant Professor at Research Cum Development Project on Cattle, Mahatma Phule Krishi Vidyapeeth, Rahuri, Maharashtra State and engaged in Diagnostic and Treatment aspect of Ruminants

AsHISH Roy is currently working as a Professor at Department of Veterinary Microbiology, College of Veterinary Science, Anand, and involved in teaching and research activities of Veterinary Microbiology at Anand, Gujarat State.

BHARAT BHANDERI is currently working as a Veterinary Officer in Gujarat State. He completed his Ph.D in Veterinary Microbiology at Anand, Gujarat State.

R.G. JANI is currently working as a Professor in Department of Veterinary Medicine at College of Veterinary Science, Anand, and involved in teaching and research activities of Veterinary Medicine at Anand, Gujarat State. He is also Wildlife co-ordinator of West Zone of India.

Author Contribution: MMY Involved in biochemical and molecular characterization of Listeria spp. Especially the work on DNA extraction from Listeria Colonies, five virulence associated gene identification by PCR. AR involved in molecular characterization of Listeria Spp especially on identification of serovars. by multiplex PCR. BB Involved in isolation of Listeria spp. Using enrichment and selective media. RJJ Involved in sample collection from wildlife and its further transport and processing at lab. 